\title{
SAKHA -1 NEW CULTIVAR OF OKRA
}

Metwally, E. I. ; A. M. Masoud ${ }^{\star *}$; Y. B. El-Waraky ${ }^{\star *}$ and M.H. Kasem ${ }^{\star \star}$

" Horticulture Dept., Faculty of Agric., Kafr EL-Sheikh Univ., Egypt

${ }^{* *}$ Veg. Res. Dept., Hort. Res. Inst., Agric. Res. Center, Giza, Egypt

\begin{abstract}
This investigation carried out in co-operation work between Horticulture Department, Faculty of Agriculture, Kafr El-Sheikh and Horticulture Research Institute during the period of 2001 to 2010 through two stages. The first stage: Six strains of okra were obtained after six generations of inbreeding and selection from the local cultivars. The six selected strains and the original cultivars were evaluated during the summer season of 2006 for yield and horticultural characteristics. Evaluation results indicated that the, Strain No. 1 had the lowest values of vegetative traits and it produced the largest values of early and total yield as a number and weight of pods, therefore, this strain was chosen as a new cultivar under name of Sakha-1 after produced their seeds in isolated area in two successive years. The second stage: The new cultivar and two commercial cultivars, i.e., Balady Green and Sabahia -1 cultivars were evaluated in summer seasons of 2009 and 2010 in the Experimental Farm of Sakha Agricultural Research Station. The new cultivar Skha-1 surpassed the Balady Green and Sabahia -1 cultivars for early and total yield as a number and weight of pods and pod quality.
\end{abstract}

\section{INTRODUCTION}

Okra [Abelmoschus esculentus (L.) Moench], $2 \mathrm{n}=2 \mathrm{x}=130$. It is an important fruit vegetable crop of the tropical and subtropical regions of the world. In Egypt, it is one of the most popular vegetables and considered a valuable source of calcium, iron and vitamins. It has been grown for its edible green pods which can be used as fresh, canned, frozen, or dried food.

Okra is considered one of the partial allogamous crops, since its natural cross pollination exceeded $20 \%$ (Tindal, 1983), subsequently variation in its characteristics could be expected. Some characteristics of okra such as, plant height, branch number, color of veins and base of leaf, leaf lobes, pod type, pod color, pod pubescence and earliness proved its simply inheritance and high heritability (Martin et al., 1981 and Ariyo, 1990), as well as number of pods per plant which is very important character.

Many researchers noticed high variations for the previous characteristics in the Egyptian local cultivars of okra (Abd El-Maksoud et al., 1984; Damarany and Farag, 1994; Hussein, 1994 and Masoud, et al., 2007).

Pod yield represented as a number and weight of pods per unit area (square meter or fedden) is very important economic character, since selection has to be applied simultaneously to all of its components and quality characters (Falconer, 1960).

There are great variations in vegetative growth, earliness, productivity and pods quality in okra plants growth in Kafr EL- Sheikh Governorate. Therefore, pure line selections which used in this study were evaluated to select superior strain (strain 1) from the local cultivars through inbreeding and 
Metwally, E. I. et al.

selection programs and comperd this strain with the two local cultivars of okra, i.e., Balady Green and Sabahia 1.

\section{MATERIALS AND METHODS}

This work was carried out at Sakha Agricultural Research Station, during the summer seasons of 2009 and 2010. Great variations in plant vigor, earliness, productivity and pod characteristics are present in local cultivars of okra plants grown in Kafr El-Sheikh Governorate. Selection of individual plants based on earliness, high number of pods, uniformity of plant phenotypie with moderate vegetative growth and uniformity of fruit color (pale green) and shape was carried out. Inbreeding and selection for chosen plants were carried out for six successive generations, the pollination technique method described by Lee (1980) was followed. After six generations of inbreeding and selection, six strains were selected. The six selected strains as well as the original cultivars were evaluated during the summer season of 2006 at a private farm in Disuq district, Kafr El-Sheikh Governorate. In isolation area, seeds of the best strain were produced in summer seasons of 2007 and 2008. The best strain was selected as a new cultivar of okra under the name of Sakha -1 (Masoud et al, 2007).

In the summer seasons of 2009 and 2010, the new cultivar (Sakha-1) besides Sabahia -1 and Balady Green cultivars of okra were evaluated in the Experimental Farm of Sakha Agricultural Research Station, seeds were sown on April $18^{\text {th }}$. The experimental plot area was $22.5 \mathrm{~m}^{2}$, including 5 rows, each of $6 \mathrm{~m}$ length and $75 \mathrm{~cm}$ width using one plant per hill with $20 \mathrm{~cm}$ apart. The cultural practices were regularly done according to the general program of okra cultivation as reported by Egyptian Ministry of Agriculture.

\section{The following data were recorded:}

\section{Vegetative traits}

Five plants were uprooted from each plot after 55 days from sowing, and the following data were recorded: 1) Stem length $(\mathrm{cm}), 2)$ Number of branches per plant, 3) Number of leaves per plant, 4) Plant fresh weight (g), and 5) Leaf area per plant $\left(\mathrm{cm}^{2}\right)$. Also, five plants were uprooted from each plot after 120 days from sowing, and the following data were recorded: 1) Stem length $(\mathrm{cm}), 2)$ Number of nodes on main stem, 3) Internode length $(\mathrm{cm}), 4)$ Number of branches per plant, and 5) Number of leaves per plant.

\section{Earliness}

Earliness was recorded as number of nodes to the first flower and number of elapsed days from sowing to first flower anthesis.

\section{Early and total pods yield}

Early and total yield expressed as total number of pods per plant and weight of pods ( $\mathrm{kg}$ per fed.) were recorded. Early yield was determined from the first four pickings, and twenty harvests were recorded and calculated as the total yield.

\section{Pods characteristics}

At the $5^{\text {th }}$ picking, ten flowers were labeled in each plot, after six days from anthesis pods were picked as reported by Metwally and Etman (1992), and 
the following data were recorded: pod weight $(\mathrm{g})$, pod length $(\mathrm{cm})$, pod diameter $(\mathrm{cm})$, peduncle length $(\mathrm{cm})$ and peduncle weight $(\mathrm{g})$.

\section{Description of selected strains}

All observations determined by measurement, weighting or counting were done on 20 plants or parts taken from each of the 20 plants. All observations on the fruits were recorded on the young fruits at commercial harvest stage ( six days from anthesis). All observations on the stem, the leaf blade and the petiole were made on the $10^{\text {th }}$ to $15^{\text {th }}$ nodes of the main stem (UPOV, 1999).

\section{Statistical Analysis}

Data were statistical by analysis of variance, and Duncan's multiple range test was used for the comparisons among the genotype means (Duncan, 1955).

\section{RESULTS AND DISCUSSION}

\section{Vegetative traits}

Data presented in Table (1) show that the differences among the Sakha$1 \mathrm{cv}$. and the original cultivars of okra were significant for all studied traits; i.e., stem length, number of branches per plant, number of leaves per plant, plant fresh weight and leaf area per plant. Balady Green cv. showed the largest values of stem length $(40.8$ and $45.3 \mathrm{~cm})$, number of branches per plant (2.9 and 3.1), number of leaves per plant (12.8 and 14.2), plant fresh weight $\left(109.4\right.$ and $115.3 \mathrm{~g}$ ) and leaf area per plant $\left(1801.5\right.$ and $\left.1895.8 \mathrm{~cm}^{2}\right)$, while Sakha $-1 \mathrm{cv}$. produced the lowest values for all the studied vegetative traits, i.e., stem length $(26.5$ and $28.8 \mathrm{~cm})$, number of branches per plant $(0.0$ and 0.2), number of leaves per plant (8.1 and 10.0), plant fresh weight (79.5 and $88.9 \mathrm{~g})$ and leaf area per plant $\left(1265.3\right.$ and $\left.1300.5 \mathrm{~cm}^{2}\right)$ in 2009 and 2010 ,respectively .

Table (1): Vegetative and flowering traits of the three cultivars of okra after 55 days from sowing in 2009 and 2010 seasons.

\begin{tabular}{|c|c|c|c|c|c|c|c|c|c|c|c|c|c|c|}
\hline \multirow{3}{*}{ Cultivars } & \multicolumn{10}{|c|}{ Vegetative traits } & \multicolumn{4}{|c|}{ Flowering traits } \\
\hline & \multirow{2}{*}{\multicolumn{2}{|c|}{\begin{tabular}{|c|c|}
\multicolumn{2}{|c|}{$\begin{array}{c}\text { Stem } \\
\text { length } \\
\text { (cm) }\end{array}$} \\
2009 & 2010 \\
\end{tabular}}} & \multicolumn{2}{|c|}{\begin{tabular}{|c|}
$\begin{array}{c}\text { No. of } \\
\text { branches } \\
\text { /plant }\end{array}$ \\
\end{tabular}} & \multicolumn{2}{|c|}{$\begin{array}{l}\text { No. of } \\
\text { leaves } \\
\text { /plant }\end{array}$} & \multicolumn{2}{|c|}{$\begin{array}{l}\text { Plant fresh } \\
\text { Weight (g) }\end{array}$} & \multicolumn{2}{|c|}{$\begin{array}{l}\text { Leaf area / } \\
\text { plant }\left(\mathrm{cm}^{2}\right)\end{array}$} & \multicolumn{2}{|c|}{$\begin{array}{l}\text { Nods to } \\
\text { first } \\
\text { flower }\end{array}$} & \multicolumn{2}{|c|}{$\begin{array}{l}\text { Days to } \\
\text { flowering }\end{array}$} \\
\hline & & & 2009 & 2010 & 2009 & 2010 & 2009 & 2010 & 2009 & 2010 & 2009 & 2010 & 2009 & 2010 \\
\hline \multirow[t]{2}{*}{ Sakha-1 } & 26.5 & 28.8 & 0.1 & 0.2 & 8.1 & 10.0 & 79.5 & 88.9 & 1265.3 & 1300.5 & 3.4 & 3.5 & 48.9 & 49.0 \\
\hline & C & $\mathrm{C}$ & $\mathrm{C}$ & $\mathrm{C}$ & $\mathrm{b}$ & $\mathrm{b}$ & $\mathrm{C}$ & $\mathrm{C}$ & $\mathrm{C}$ & C & $\mathrm{C}$ & $\mathrm{C}$ & C & C \\
\hline Balady & 40.8 & 45.3 & 2.9 & 3.1 & 12.8 & 14.2 & 109.4 & 115.3 & 1801.5 & 1895.8 & 6.0 & 6.5 & 60.1 & 62.0 \\
\hline Green & $a$ & a & $\mathrm{a}$ & $\mathrm{a}$ & $a$ & a & $\mathrm{a}$ & a & $\mathrm{a}$ & a & a & $\mathrm{a}$ & $\mathrm{a}$ & a \\
\hline \multirow[t]{2}{*}{ Sabahia-1 } & 32.4 & 36.2 & 2.1 & 2.5 & 11.3 & 11.5 & 100.8 & 109.5 & 1713.0 & 1769.5 & 5.1 & 5.5 & 55.8 & 56.1 \\
\hline & $\mathrm{b}$ & $\mathrm{b}$ & $\mathrm{b}$ & $\mathrm{b}$ & $a b$ & $\mathrm{~b}$ & $\mathrm{~b}$ & $b$ & $\mathrm{~b}$ & & $\mathrm{~b}$ & $b$ & b & $b$ \\
\hline
\end{tabular}

Means designated by the same letter are not significantly different at 0.05 level, of probability, according to Duncan's test.

Data in Table (2) show that the same trend was notice in vegetative traits, i.e., stem length, number of nodes on main stem, internode length, number of branches per plant and number of leaves per plant after 120 days from sowing, except for number of nodes on the main stem as Sakha $-1 \mathrm{cv}$. produced the highest number, while Balady Green cv. Gave the lowest one. 
The significant differences among the Sakha- 1, Balady Green and Sabahia - 1 cultivars in the vegetative traits indicate that variations among the three cultivars of okra are due to genetic differences. Early work indicated high variations for vegetative traits of the Egyptian local cultivars of okra (Ragheb et al., 1994, Abo El-khar 2003 and Masoud et al., 2007)

Table (2): Vegetative traits of the three cultivars of okra after 120 days from sowing in 2009 and 2010 seasons.

\begin{tabular}{|c|c|c|c|c|c|c|c|c|c|c|}
\hline \multirow{3}{*}{ Cultivars } & \multicolumn{10}{|c|}{ Vegetative traits } \\
\hline & \multicolumn{2}{|c|}{$\begin{array}{l}\text { Stem length } \\
\text { (cm) }\end{array}$} & \multicolumn{2}{|c|}{$\begin{array}{l}\text { No. of nodes on } \\
\text { main stem }\end{array}$} & \multicolumn{2}{|c|}{$\begin{array}{l}\text { Internode } \\
\text { length }(\mathrm{cm})\end{array}$} & \multicolumn{2}{|c|}{\begin{tabular}{|c|} 
No of \\
branches/ plant
\end{tabular}} & \multicolumn{2}{|c|}{$\begin{array}{l}\text { No. of leaves } \\
\text { / plant }\end{array}$} \\
\hline & 2009 & 2010 & 2009 & 2010 & 2009 & 2010 & 2009 & 2010 & 2009 & 2010 \\
\hline Sakha -1 & 108.5 & 115.7 & 42.5 & 45.7 & 2.0 & 2.2 & 0.5 & 0.6 & 28.3 & 30.5 \\
\hline & C & C & a & a & C & C & C & C & C & C \\
\hline Balady & 135.8 & 140.2 & 14.3 & 15.5 & 9.5 & 9.6 & 4.5 & 5.0 & 53.9 & 59.2 \\
\hline Green & a & $\mathrm{a}$ & $\mathrm{C}$ & $\mathrm{C}$ & $\mathrm{a}$ & $\mathrm{a}$ & $a$ & $\mathrm{a}$ & $\mathrm{a}$ & a \\
\hline Sabahia - 1 & 128.6 & 130.8 & 19.6 & 20.0 & 6.4 & 6.9 & 3.2 & 3.5 & 49.5 & 51.3 \\
\hline
\end{tabular}

Means designated by the same letter are not significantly different at 0.05 level, of probability, according to Duncan's test.

\section{Flowering traits}

It is obvious from Table (1) that Sakha $-1 \mathrm{cv}$. was earlier in flowering than the other cultivars. Differences among Sakha $-1 \mathrm{cv}$. and original cultivars were significant for number of nodes to the first flower and number of days from sowing to flowering (Table 1). The new cultivar (Sakha-1) had the lowest number of nodes to the first flower (3.4 and 3.5), while, Balady green cultiver had the highest number of nodes to the first flower (6.0 and 6.5). The number of days from sowing to flowering ranged from 48.9 and 49.0 days in Sakha -1 cv. to 60.1 and 62.0 days in Balady green cv in 2009 and 2010, respectively.

Okra plants which bear the first flower on a lower node, and need fewer days to flowering will be earlier than those bearing the first flower on a higher node and need more days to flowering (Metwally et al. 1988). Therefore, Sakha - $1 \mathrm{cv}$. was earlier than the other original cultivars.

Early and total pods yield

Data in Table (3) indicate that Sakha $-1 \mathrm{cv}$. produced higher early yield than Sabahia -1 and Balady Green cvs.

Table (3): Early and total yield of the three cultivars of okra in 2009 and 2010 seasons.

\begin{tabular}{|c|c|c|c|c|c|c|c|c|}
\hline \multirow[t]{3}{*}{ Cultivars } & \multicolumn{4}{|c|}{ Early yield } & \multicolumn{4}{|c|}{ Total yield } \\
\hline & \multicolumn{2}{|c|}{$\begin{array}{l}\text { No. of pods } \\
\text { /plant }\end{array}$} & \multicolumn{2}{|c|}{$\begin{array}{l}\text { Pods weight } \\
\text { (kg/fed.) }\end{array}$} & \multicolumn{2}{|c|}{$\begin{array}{l}\text { No. of pods } \\
\text { / plant }\end{array}$} & \multicolumn{2}{|c|}{$\begin{array}{c}\text { Pods weight } \\
\text { (kg/fed.) }\end{array}$} \\
\hline & 2009 & 2010 & 2009 & 2010 & 2009 & 2010 & 2009 & 2010 \\
\hline \multirow[t]{2}{*}{ Sakha -1 } & 11.5 & 12.2 & 908.5 & 963.8 & 39.7 & 42.5 & 6285.8 & 6729.1 \\
\hline & $\mathrm{a}$ & a & $\mathrm{a}$ & a & $\mathrm{a}$ & a & $\mathrm{a}$ & a \\
\hline \multirow[t]{2}{*}{ Balady Green } & 0.8 & 1.2 & 120.5 & 180.8 & 17.9 & 19.4 & 2273.3 & 2463.8 \\
\hline & $\mathrm{C}$ & C & C & C & C & $\mathrm{C}$ & C & C \\
\hline Sabahia -1 & $\begin{array}{c}1.5 \\
b\end{array}$ & $\begin{array}{c}2.1 \\
b\end{array}$ & $\begin{array}{c}235.7 \\
b\end{array}$ & $\begin{array}{c}324.0 \\
b\end{array}$ & $\begin{array}{c}23.7 \\
b\end{array}$ & $\begin{array}{c}25.8 \\
b\end{array}$ & $\begin{array}{c}3143.6 \\
b\end{array}$ & $\begin{array}{c}3422.1 \\
b\end{array}$ \\
\hline
\end{tabular}
probability, according to Duncan's test. 
Data elicit that the differences were significant for early pods yield, as a number and weight of pods. Sakha-1 cv. produced the highest values for number of pods per plant with a value of 11.5 and 12.2 and pods weight with 908.5 and $963.8 \mathrm{~kg}$ per fed. in 2009 and 2010, respectively. The superiority of Sakha $-1 \mathrm{cv}$. for early yield as a number and weight may be due to its early flowering compared with the other cultivars.

As for the total yield; i.e., number of pods per plant and pod weight $(\mathrm{kg} / \mathrm{fed}$.), data in Table (3) show that Sakha $-1 \mathrm{cv}$. surpassed the original cultivars. Sakha $-1 \mathrm{cv}$. produced the largest values of total pods yield as number and weight with 39.7 and 42.5 pods per plant and 6285.8 and 6729.1 $\mathrm{kg}$ per fedden. However, Balady Green cultivar produced the lowest values of total pods yield as number and weight with 17.9 and 19.4 pods per plant and 2273.3 and $2463.8 \mathrm{~kg}$ per fedden in 2009 and 2010, respectively. The differences among Sakha $-1 \mathrm{cv}$. and other original cultivars for total pods yield were significant. The superiority of Sakha $-1 \mathrm{cv}$. is due to the higher number of pods produced per plant compared with the other original cultivars. Many investigators noticed high variation for pods yield of the Egyptian local cultivars of okra (Abd El-hafez and Salah, 1977; Damarany and Farag, 1994; Hussein, 1994; Ragheb et al., 1994 Abo El-khar, 2003 and Massoud et al., 2007).

\section{Pod characteristics}

Data presented in Table (4) show that pod length ranged from 4.3 and $4.0 \mathrm{~cm}$ for Balady Green cultivar to 5.6 and $5.5 \mathrm{~cm}$ for Sakha $-1 \mathrm{cv}$. Pod diameter ranged from $1.5 \mathrm{~cm}$ for Sakha $-1 \mathrm{cv}$. to 1.8 and $2.0 \mathrm{~cm}$ for Balady Green cultivar. The length of peduncle of pods ranged from 3.3 and $3.0 \mathrm{~cm}$ for Balady Green cultivar to 4.9 and $4.8 \mathrm{~cm}$ for Sakha $-1 \mathrm{cv}$. Average pod weight was 3.95, 3.90 and 4.85, $4.70 \mathrm{~g}$. for Sakha $-1 \mathrm{cv}$. and Sabahia 1 in 2009 and 2010, respectively. Average peduncle weight was 1.50, 1.46 and 2.60, 2.58 g. for Balady Green cultivar and Sakha -1 cv. in 2009 and 2010, respectively.

Table (4): Pods characteristics of the three cultivars of okra after 6 days from anthesis in 2009 and 2010 seasons.

\begin{tabular}{|c|c|c|c|c|c|c|c|c|c|c|}
\hline \multirow[t]{2}{*}{ Cultivars } & \multicolumn{2}{|c|}{$\begin{array}{l}\text { Average pod } \\
\text { length } \\
(\mathrm{cm})\end{array}$} & \multicolumn{2}{|c|}{$\begin{array}{l}\text { Average pod } \\
\text { diameter } \\
\text { (cm) }\end{array}$} & \multicolumn{2}{|c|}{$\begin{array}{l}\text { Average pod } \\
\text { weight } \\
\text { (g) }\end{array}$} & \multicolumn{2}{|c|}{$\begin{array}{l}\text { Average } \\
\text { peduncle } \\
\text { length } \\
\text { (cm) }\end{array}$} & \multicolumn{2}{|c|}{$\begin{array}{l}\text { Average } \\
\text { peduncle } \\
\text { weight } \\
\text { (g) }\end{array}$} \\
\hline & 2009 & 2010 & 2009 & 2010 & 2009 & 2010 & 2009 & 2010 & 2009 & 2010 \\
\hline Sakha -1 & $\begin{array}{c}5.6 \\
a\end{array}$ & $\begin{array}{c}5.5 \\
\mathrm{a}\end{array}$ & $\begin{array}{c}1.5 \\
b\end{array}$ & $\begin{array}{c}1.5 \\
b\end{array}$ & $\begin{array}{c}3.95 \\
b\end{array}$ & $\begin{array}{c}3.90 \\
b\end{array}$ & $\begin{array}{c}4.9 \\
a\end{array}$ & $\begin{array}{c}4.8 \\
a\end{array}$ & $\begin{array}{c}2.60 \\
a\end{array}$ & $\begin{array}{c}2.58 \\
a\end{array}$ \\
\hline Balady Green & $\begin{array}{c}4.3 \\
b\end{array}$ & $\begin{array}{c}4.0 \\
b\end{array}$ & $\begin{array}{c}1.8 \\
\mathrm{a}\end{array}$ & $\begin{array}{c}2.0 \\
a\end{array}$ & $\begin{array}{c}4.32 \\
a b\end{array}$ & $\begin{array}{c}4.10 \\
b\end{array}$ & $\begin{array}{c}3.3 \\
\mathrm{C}\end{array}$ & $\begin{array}{c}3.0 \\
c\end{array}$ & $\begin{array}{c}1.50 \\
c\end{array}$ & $\begin{array}{c}1.46 \\
\mathrm{C}\end{array}$ \\
\hline Sabahia -1 & $\begin{array}{l}5.3 \\
a b\end{array}$ & $\begin{array}{l}5.2 \\
a b\end{array}$ & $\begin{array}{l}1.7 \\
a b\end{array}$ & $\begin{array}{c}1.8 \\
b\end{array}$ & $\begin{array}{c}4.85 \\
a\end{array}$ & $\begin{array}{c}4.70 \\
a\end{array}$ & $\begin{array}{l}3.9 \\
b c\end{array}$ & $\begin{array}{l}4.1 \\
a b\end{array}$ & $\begin{array}{c}1.85 \\
b c\end{array}$ & $\begin{array}{c}1.90 \\
b\end{array}$ \\
\hline
\end{tabular}

Means designated by the same letter are not significantly different at 0.05 level, of probability, according to Duncan's test.

It is clear from the pod characteristics that the differences among the new cultivar Sakha - 1 and the two original cultivars of okra were significant. These data confirm that Sakha $-1 \mathrm{cv}$. is genetically different than the original cultivars. 


\section{Metwally, E. l. et al.}

1. Egyptian investigators noticed high variations for pod characteristics of the Egyptain cultivars of okra (Damarany and Farag, 1994; Hussein, 1994; Abo El-khar, 2003 and Masoud et al., 2007).

\section{Description of the the new and original cultivars}

Data presented in Table (5) show that the differences among the Sakha-1 cv. and the original cultivars of okra, according to UPOV guideline.

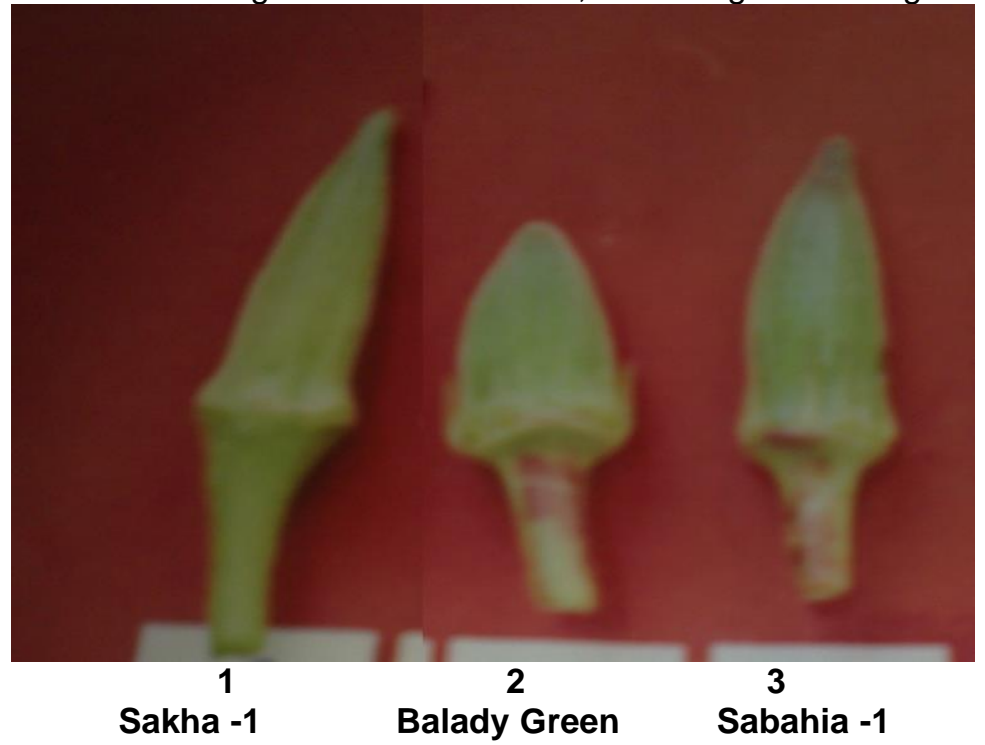

Fig. (1): Size and shape of pods after six days from anthesis of the three studied cultivars.

Table (5): Description of Sakha $\mathbf{- 1 ~ c v . ~ a n d ~ t h e i r ~ o r i g i n a l ~ c u l t i v a r s ~ o f ~ o k r a ~}$ according to UPOV guideline.

\begin{tabular}{|c|c|c|c|}
\hline Characteristics $^{1}$ & Character states & Cultivars & Note $^{\star *}$ \\
\hline 1. Plant: degree of branching & $\begin{array}{l}\text { Weak } \\
\text { Medium } \\
\text { Strong }\end{array}$ & $\begin{array}{l}\text { Sakha -1 } \\
\text { Sabahia -1 } \\
\text { Balady Green }\end{array}$ & $\begin{array}{l}3 \\
5 \\
7\end{array}$ \\
\hline 2. Plant: height & $\begin{array}{l}\text { Short } \\
\text { Medium } \\
\text { Tall }\end{array}$ & $\begin{array}{l}\text { Sakha -1 } \\
\text { Sabahia -1 } \\
\text { Balady Green }\end{array}$ & $\begin{array}{l}3 \\
5 \\
7\end{array}$ \\
\hline 3. Stem: diameter & $\begin{array}{l}\text { Small } \\
\text { Medium } \\
\text { Large }\end{array}$ & $\begin{array}{l}\text { Sakha-1,Sabahia-1, } \\
\text { Balady Green }\end{array}$ & $\begin{array}{l}3 \\
5 \\
7\end{array}$ \\
\hline 4. Stem: color & Green & $\begin{array}{l}\text { Sakha-1,Sabahia-1, } \\
\text { Balady Green }\end{array}$ & $\begin{array}{l}1 \\
2\end{array}$ \\
\hline 5. Stem: intensity of color & $\begin{array}{l}\text { Light } \\
\text { Medium } \\
\text { Dark }\end{array}$ & $\begin{array}{l}\text { Sakha-1,Sabahia-1, } \\
\text { Balady Green }\end{array}$ & $\begin{array}{l}3 \\
5 \\
7\end{array}$ \\
\hline $\begin{array}{l}\text { 6. Stem: number of nodes (up to and } \\
\text { including the first flowering node) }\end{array}$ & $\begin{array}{l}\text { Few } \\
\text { Medium } \\
\text { Many }\end{array}$ & $\begin{array}{l}\text { Sakha-1 } \\
\text { Sabahia-1 } \\
\text { Balady Green }\end{array}$ & $\begin{array}{l}3 \\
5 \\
7\end{array}$ \\
\hline
\end{tabular}


J. Plant Production, Mansoura Univ., Vol. 2 (6), June, 2011

\begin{tabular}{|c|c|c|c|}
\hline 7. Leaf blade: size & $\begin{array}{l}\text { Small } \\
\text { Medium } \\
\text { Large }\end{array}$ & $\begin{array}{l}\text { Sakha-1,Sabahia -1 } \\
\text { Balady Green }\end{array}$ & $\begin{array}{l}3 \\
5 \\
7\end{array}$ \\
\hline 8. Leaf blade: depth of lobbing* & $\begin{array}{l}\text { Shallow } \\
\text { Medium } \\
\text { Deep }\end{array}$ & $\begin{array}{l}\text { Sakha-1,Sabahia-1, } \\
\text { Balady Green }\end{array}$ & $\begin{array}{l}3 \\
5\end{array}$ \\
\hline 9. Leaf blade: denotation of margin & $\begin{array}{l}\text { Weak } \\
\text { Medium } \\
\text { Strong }\end{array}$ & $\begin{array}{l}\text { Sakha-1,Sabahia-1, } \\
\text { Balady Green }\end{array}$ & $\begin{array}{l}3 \\
5\end{array}$ \\
\hline 10. Leaf blade: color between veins ${ }^{*}$ & Red & $\begin{array}{l}\text { Sakha-1,Sabahia-1, } \\
\text { Balady Green }\end{array}$ & 1 \\
\hline $\begin{array}{l}\text { 11. Leaf blade: intensity of color between } \\
\text { veins }\end{array}$ & $\begin{array}{l}\text { Light } \\
\text { Medium } \\
\text { Dark }\end{array}$ & $\begin{array}{l}\text { Sakha-1,Sabahia-1, } \\
\text { Balady Green }\end{array}$ & $\begin{array}{l}3 \\
5\end{array}$ \\
\hline 12. Petiole: length & $\begin{array}{l}\text { Short } \\
\text { Medium } \\
\text { Long }\end{array}$ & $\begin{array}{l}\text { Sakha-1,Sabahia-1, } \\
\text { Balady Green }\end{array}$ & $\begin{array}{l}3 \\
5\end{array}$ \\
\hline 13. Petiole: diameter & $\begin{array}{l}\text { Small } \\
\text { Medium } \\
\text { Large }\end{array}$ & $\begin{array}{l}\text { Sakha-1,Sabahia-1, } \\
\text { Balady Green }\end{array}$ & $\begin{array}{l}3 \\
5\end{array}$ \\
\hline 14. Flower: size & $\begin{array}{l}\text { Small } \\
\text { Medium } \\
\text { Large }\end{array}$ & $\begin{array}{l}\text { Sabahia-1,Balady } \\
\text { Green } \\
\text { Sakha-1 }\end{array}$ & $\begin{array}{l}3 \\
5\end{array}$ \\
\hline 15. Fruit: color ${ }^{*}$ & Red & $\begin{array}{l}\text { Sakha-1,Sabahia-1, } \\
\text { Balady Green }\end{array}$ & 1 \\
\hline 16. Fruit: intensity of color & $\begin{array}{l}\text { Light } \\
\text { Medium } \\
\text { Dark }\end{array}$ & \begin{tabular}{ll|} 
Sabahia -1 & \\
Sakha-1, & Balady \\
Green &
\end{tabular} & $\begin{array}{l}3 \\
5\end{array}$ \\
\hline $\begin{array}{l}\text { 17. Fruit: diameter of young fruit (at mid } \\
\text { length) }\end{array}$ & $\begin{array}{l}\text { Small } \\
\text { Medium } \\
\text { Large }\end{array}$ & $\begin{array}{ll}\text { Sakha -1 } & \\
\text { Sabahia-1, } & \text { Balady } \\
\text { Green } & \end{array}$ & $\begin{array}{l}3 \\
5\end{array}$ \\
\hline 18. Fruit: surface between ridges* & $\begin{array}{l}\text { Concave } \\
\text { Flat } \\
\text { Convex }\end{array}$ & $\begin{array}{l}\text { Sakha-1,Sabahia-1, } \\
\text { Balady Green }\end{array}$ & $\begin{array}{l}3 \\
5\end{array}$ \\
\hline 19. Fruit: constriction of basal part & $\begin{array}{l}\text { Absent or very } \\
\text { weakly expressed } \\
\text { Weakly expressed } \\
\text { Strongly } \\
\text { expressed }\end{array}$ & Sakha-1,Sabahia-1 & $\begin{array}{l}2 \\
3\end{array}$ \\
\hline 20. Fruit: shape of apex & \begin{tabular}{l|} 
Narrow acute \\
Acute \\
Broad acute
\end{tabular} & $\begin{array}{l}\text { Sakha-1,Sabahia-1, } \\
\text { Balady Green }\end{array}$ & $\begin{array}{l}2 \\
3\end{array}$ \\
\hline 21. Fruit: number of locules ${ }^{*}$ & $\begin{array}{l}\text { Five } \\
\text { More than five }\end{array}$ & $\begin{array}{l}\text { Sakha-1,Sabahia-1, } \\
\text { Balady Green }\end{array}$ & 1 \\
\hline
\end{tabular}


Metwally, E. I. et al.

\begin{tabular}{|c|c|c|c|}
\hline 22. Fruit: thickness of carpel & $\begin{array}{l}\text { Thin } \\
\text { Medium } \\
\text { Thick }\end{array}$ & $\begin{array}{l}\text { Sakha -1 } \\
\text { Sabahia-1,Balady } \\
\text { Green }\end{array}$ & $\begin{array}{l}3 \\
5 \\
7\end{array}$ \\
\hline 23. Fruit: length of mature fruit & $\begin{array}{l}\text { Short } \\
\text { Medium } \\
\text { Long }\end{array}$ & $\begin{array}{l}\text { Balady Green } \\
\text { Sabahia -1 } \\
\text { Sakha -1 }\end{array}$ & $\begin{array}{l}3 \\
5 \\
7\end{array}$ \\
\hline $\begin{array}{l}\text { 24. Fruit: diameter of mature fruit (at mid } \\
\text { length) }\end{array}$ & $\begin{array}{l}\text { Small } \\
\text { Medium } \\
\text { Large }\end{array}$ & $\begin{array}{l}\text { Sakha-1,Sabahia-1 } \\
\text { Balady Green }\end{array}$ & $\begin{array}{l}3 \\
5 \\
7\end{array}$ \\
\hline 25. Time of flowering & $\begin{array}{l}\text { Early } \\
\text { Medium } \\
\text { Late }\end{array}$ & $\begin{array}{l}\text { Sakha }-1 \\
\text { Sabahia }-1 \\
\text { Balady Green }\end{array}$ & $\begin{array}{l}3 \\
5 \\
7\end{array}$ \\
\hline 26. Time of commercial harvest & $\begin{array}{l}\text { Early } \\
\text { Medium } \\
\text { Late }\end{array}$ & $\begin{array}{l}\text { Sakha -1 } \\
\text { Sabahia -1 } \\
\text { Balady Green }\end{array}$ & $\begin{array}{l}3 \\
5 \\
7\end{array}$ \\
\hline
\end{tabular}

(1) To asses distinctness, uniformity and stability, the characteristics and their states as given in the table of characteristics should be used.

$\left({ }^{*}\right)$ Characteristics that should be used on all lines in every growing period over which the examinations are made and always be included in the lines description, except when the state of expression of a preceding characteristic or regional environmental conditions render this impossible.

$\left({ }^{\star *}\right)$ Notes (number, for the purposes of electronic data processing, are given opposite the states of expression for each characteristic.

\section{REFERENCES}

Abd El-Hafez, A.A. and M. Salah (1977). Comparative studies on exotic and strains of Egyptian local cultivars characters in okra. J. Agric. Sci. Mansoura Univ. 2:247-258.

Abd El-Maksoud, M.A.; R.M. Hela and M.H. Mohamed (1984). Heritablility estimates and correlation studies of six economic characters in okra. Annals of Agric. Sci., Ain Shams Univ. 29: 439-452.

Abo El-Khar, Y.Y. (2003). Efficiency of selection with inbreeding on improving some characteristics in the Balady cultivar of okra. M.Sc. Thesis Fac. Agric., Alex. Univ., Egypt. Pp: 111.

Ariyo, O.J. (1990). Variation and heritability of fifteen characters in okra [Abelmoschus esculentus (L.) Moench]. Trop. Agric. 67: 213-216.

Damarany A.M. and I.A. Farag (1994). An evaluation of growth, yield and quality of some okra cultivars and strains under Assiut /conditions. Assuit J. Agric. Sci. 25: 57-70.

Duncan, B.D. (1955). Multiple ranges and multiple F-test. Biometrics, 11:1-42.

Falconer, D.S. (1960). Introduction to quantitative genetics. The Ronald Press Co. N.Y. 365p.

Hussein, H.A. (1994). Variation, heritability and response to selection in okra. Assiut. J. Agric. Sci. 25: 193-202.

Lee, J.A. (1980). Cotton in: Fehr, W.R. and H.H. Hadley (eds.) Hybridization of crop plants. Amer. Soci. Agron. And Crop Sci. Soci. Amer., Publi. Madison, Wisconsin, USA.

Martin, F.M.; A.M. Rhodes, M. Ortiz and F. Diaz (1981). Variation in okra. Euphytica, 30:697-705. 
Masoud, A.M.; Y.B. El-Waraky; T.A. Shalaby and M.H. Kasem (2007). Developing new strains of okra. J. Agric. Sci. Mansoura Univ., 32 (1): 583-590.

Metwally, E.I and A.A. Etman (1992). Diallel cross analysis of yield and related traits of okra in winter season under plastic house condition. J. Agric. Res. Tanta Univ. 18: 135-147.

Metwally, E.I; B.I. El-Sawy and R.M. Khalil (1988). Heterosis and nature of gene action studies on yield and related traits of okra[Abelmoschus esculentus (L) Moench]. J. Agric. Res. Tanta Univ. 18: 1088-1105.

Ragheb, W.S.; H.A. El-Shamma and H. A. Ghazal (1994). Inheritance of yield and pod characters in okra. Zagazig J. Agric. Res. 21: 1785-1795.

Tindal, H.D. (1983). Vegetable in the tropics, P.325, MaComillan Press. London.

UPOV. (1999). Guidelines for the conduct of test for distinctness, uniformity and stability, of okra [Abelmoschus esculentus (L.) Moench]. International Union for the protection of new varieties of plants, TG/167/3, Geneva.

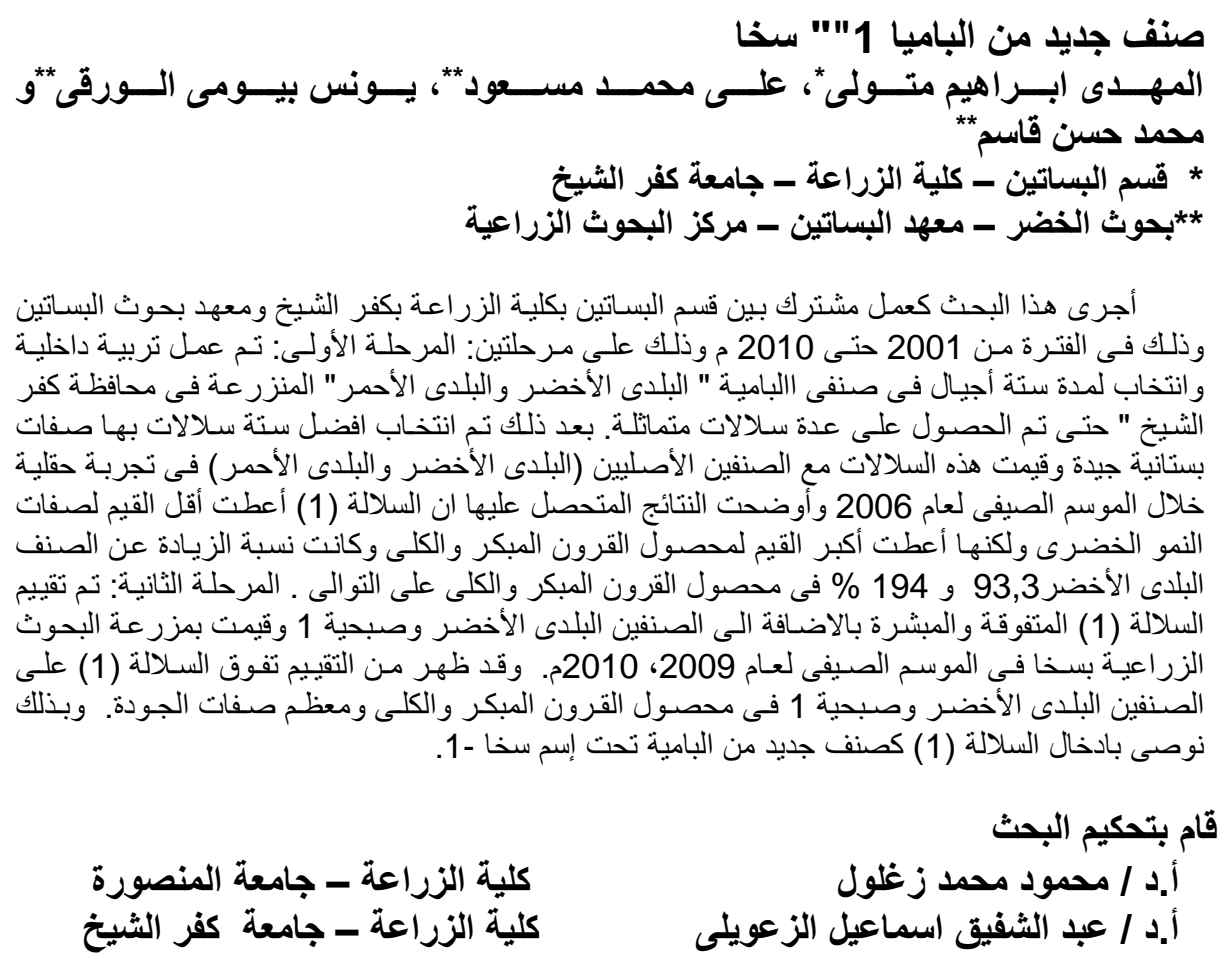

